\title{
Anacrônico, pois poeta: linguagem, memória e resistência na poesia de Paulo Henriques Britto
}

Júlio França Universidade Federal Fluminense

Tudo pode ser contemporâneo deste século, menos a poesia. Como pode o poeta adotar a linguagem e seguir as idéias e mostrar os costumes de uma geração para a qual a glória é uma fantasia, a liberdade e o amor da pátria não existem, o amor verdadeiro é uma puerilidade; em suma, onde as ilusões se esvaíram todas, e as paixões, não só as grandes e nobres e belas, mas todas as paixões se extinguiram? Um poeta, enquanto poeta, pode ser egoísta e metafísico? E o nosso século não é, tal e qual, no seu caráter? como, então, pode o poeta ser caracteristicamente contemporâneo enquanto poeta?

Giacomo Leopardi

\section{I - Linguagem e temporalidade}

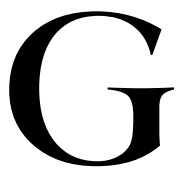

rande parte da complexidade de se abordar questões teóricas que envolvam o tempo provém de um possivelmente intransponível obstáculo cognitivo e conceitual. Ainda que não olvidemos a tarefa de definir com clareza sobre o que falamos quando nos referimos a ele, não poderemos evitar nossa limitada capacidade de compreendê-lo. Quando Kant propôs que o Tempo, assim como o Espaço, é uma construção do sujeito para dar forma às coisas, não existindo, portanto, como realidade externa, aniquilou-se o que havia de substantivo em nosso entendimento do assunto. Estavam abertas as portas para que o homem encarasse a temporalidade não apenas como uma 
inexorável e infinita seqüência de sóis, ciclos e estações, mas como um efeito fenomênico das relações do homem com o mundo.

A partir do filósofo de Koenigsberg estabeleceram-se diversas relativizações para a noção de Tempo, como o histórico, o lingüístico, o cronológico, o cósmico, o psicológico, e quaisquer outros exigidos pelo interesse específico do método científico e do aparelho conceitual empregados. Mesmo tomando-o como "categoria", modo humano de ordenação e conhecimento, não estamos a salvo de equívocos conceituais e dúvidas epistemológicas. O terreno é movediço e talvez devêssemos ouvir Wittgenstein (1991), para quem uma pergunta do tipo "que horas são?" era um problema perfeitamente solucionável, enquanto que uma inquisição sobre a natureza última do tempo é colocar-se num labirinto cuja saída única está, justamente, em se libertar da idéia de que existam labirintos.

Contornando as aporias filosóficas, falemos do tempo, em harmonia com nosso interesse estrito, exclusivamente na linguagem, onde ele parece se manifestar de maneira mais explícita. Afinal, lingüistas como Emile Benveniste (1994) não duvidam de que a temporalidade é um quadro do pensamento produzida na e pela enunciação. Essa instância discursiva, no dizer de Benedito Nunes (1988), é o ponto de emergência do presente, o tempo próprio da linguagem.

Plasmada no discurso, a categoria da temporalidade revela-se multifacetada e apresenta uma simultaneidade de instâncias temporais. Especialmente no texto poético, nosso objeto de estudo, o presente da enunciação convive com o ânimo ora memorialista, ora profético, do sujeito lírico, com os tempos internos do poemas (do ritmo, do metro, das pausas e das cesuras), com os mecanismos de repetição das formas poéticas, e com a profunda existência diacrônica da língua.

Alfredo Bosi (1977) atribui, argutamente, à ação da memória uma responsabilidade direta pelo fenômeno da coexistência de tempos no texto poético. Em sua capacidade de retenção e incitação de imagens, a memória abre um canal com o passado, que se torna subitamente presencial, seja através da evocação do ídolo, seja através da obsessão pelo tabu. Nos termos das observações de Jacques Derrida (1994) sobre a tarefa da herança, diríamos que o passado, através do trabalho da memória, obsedia de maneira espectral, pois irrompe como algo que não pertence ao momento presente, como algo de existência anacrônica - o que nos interessará sobremaneira mais adiante. 
A linguagem verbal detém, através de seu caráter lógico e serial, a ameaça constante do devaneio e da errância, provocada pela potência arrebatadora da memória como mecanismo suscitador de imagens, e transforma essa experiência numa expressão comunicável a outro sujeito. Neste processo de "conversão" da imagem em palavra, movimento de presentificação de algo in absentia, revela-se a dissimetria constitutiva da linguagem que, da mesma maneira que as faculdades da reflexão e da memória, se dá necessariamente a partir de um afastamento dos objetos sensíveis.

Na concepção de Alfredo Bosi, a diferença essencial entre os modos imagético e lingüistico de acesso ao real é que se a imagem vem como um simulacro, a palavra atua como uma substituta. Note-se que, embora o ensaísta fale em "substituição", e não em "representação", subsiste em sua distinção uma concepção de linguagem como instrumento de acesso ao real. Citando Husserl, ele chama atenção para a ocorrência do desejo de recuperar, através do signo lingüistico, "a camada préexpressiva do vivido" (apud BOSI, 1977, p. 28), proposição que sustenta a confiança em um poder fundador da linguagem de nomear as coisas.

Fazendo aqui uma rápida digressão, cuja preocupação filosófica mal disfarça a tentativa de estabelecer um posicionamento "político" dentro dos estudos de linguagem, diremos que a possibilidade de um conhecimento pré-lingüístico é um tema central da filosofia ocidental. A partir do século XVII, pensadores vêm interpondo ao essencialismo platônico a sugestão de que jamais chegaremos a conhecer a realidade, obnubilados que somos por uma barreira chamada "linguagem". Richard Rorty considera que o século XX, através de correntes filosóficas as mais diversas - como o Existencialismo, o Desconstrucionismo, o Pós-estruturalismo em geral -, vem consolidando uma tendência antiessen-cialista, seja em afirmações do tipo "tudo não passa de uma construção social" ou "toda consciência é um fato lingüístico". Afirmando que "nunca seremos capazes de pisar do lado de fora da linguagem" (RORTY, 2000, p. 57), Rorty pretende encampar essas doutrinas sob a insígnia do Pragmatismo, abolindo dicotomias clássicas, como Aparência e Realidade e alardeando, muitas vezes de modo sofismático, a impossibilidade de um conhecimento pré-lingüístico, por duvidar da possibilidade de se veicular qualquer tipo de informação que não seja de uma maneira relacional. Em outras palavras, os neopragmatistas acreditam que nossa consciência não pode apreender nada sobre a essências das coisas e dos seres, mas apenas estabelecer correlações, via linguagem, entre os elementos do mundo sensível. 
Esta filosofia, sustentáculo da atual tendência culturalista dos estudos humanos, desinstrumentaliza a discussão no campo estético. O valor da obra de arte, como o de qualquer outro objeto cultural, presta contas somente a maior ou menor funcionalidade que esta possa ter no contexto social a que pertence. Substituindo os critérios de conhecimento do mundo pelos de descrições mais ou menos úteis do mundo, sem conseguir contudo explicitar qual seria o obscuro fim desta utilidade, os pragmatistas transformam metalinguagem em tautologia, pois, afinal, como utilizar noções como "isso é melhor que aquilo", sem se recorrer a algum sistema de valores que transcendam o domínio da própria linguagem?

Voltando à proposição de Bosi, com a qual concordamos, afirmamos que a palavra, no texto poético, não "representa" algo - o que acabaria por implicar a possibilidade de uma melhor ou pior simulação da coisa original. Mas o movimento de substituição de imagem em palavra, não está livre da impregnação ideológica que a linguagem, como instituição cultural, sofre. Na passagem à palavra da coisa-substituída-pelapalavra, há um ato humano de escolha, consciente ou não. Ainda que a única verdade seja a sua materialidade ou sua existência contextual, ainda que a palavra não simule nem represente nada, ainda que a palavra não desempenhe o papel de suplente para a ausência de coisas - pessoas, objetos, fatos -, o simples ato de permitir enunciados predicativos, confere ao homem a possibilidade de uma tomada de posição diante de um mundo, cuja existência, não retornaremos à questão, pode ser exclusivamente lingüistica ou não.

Explicitado nosso entendimento de linguagem, cabe agora perguntar como se dá, no texto poético, a ação da memória mediada pela linguagem, seja como potência evocadora de imagens, seja como objeto de reflexão do sujeito lírico. Paulo Henriques Britto, no artigo "Poesia e Memória", fomentador desta monografia, estabelece a distinção fundamental entre uma memória épica e uma memória lírica. A primeira é coletiva: o poeta épico busca no passado prenúncios de uma grandeza presente ou futura de seu povo. A memória épica é a forjadora de uma narrativa que ajuda a constituir a própria idéia de coletividade.

O momento histórico de domínio da memória épica teria sido superado pelo período que conhece a ascensão dos Estados modernos. Essa forma de organização política revoluciona o sentido de comunidade e alavanca processos que levarão à constituição do indivíduo moderno e à transformação do lírico no principal gênero poético. 
Embora também seja um forjador de mitos, o poeta lírico busca em sua memória individual a matéria de seu labor poético. Ao elaborar uma "história pessoal que tenha coerência e sentido" (BRITTO in PEDROSA, 2000, p. 125), o poeta constrói um "eu" por sobre "pulsões incoerentes e mesmo contraditórias" (Ibid.). O leitor identifica-se com a própria "condição humana, configurada numa seqüência de vivências que formam um todo compartilhado pela humanidade" (Ibid.). O desafio do poeta lírico é fabricar para si um "eu" num momento em que o "conceito de sujeito individual é apontado como um anacronismo" (Ibid., p. 126. Grifo nosso) - segunda aparição da idéia, a ser desenvolvida no próximo tópico.

A poesia produzida no século XX apresentará a constituição de personalidades líricas a partir de leituras feitas pelo autor, e não de experiências em primeira mão. A memória do vivido dá lugar à memória do lido, quando a intertextualidade torna-se mais importante do que a experiência não literária. O poeta romântico sacralizava sua infância, sua memória individual. Já o poeta pós-lírico, denominação criada por Paulo Henriques Britto, sacraliza o seu cânon particular, suas leituras.

Em outro artigo, intitulado "Algumas reflexões sobre tradução e criação poética", Paulo Henriques Britto relata, de maneira autobiográfica, a difícil passagem de uma compreensão do fazer poético como expressão de sentimentos de uma identidade subjetiva, para a noção de "forja" de uma persona lírica.

No seu caso particular, a transformação se deu com a "descoberta", nos anos setenta, do Concretismo e de João Cabral de Mello Neto, quando o então jovem poeta percebeu, entre as suas limitações, que a técnica que procurava dominar "pertenciam a um passado irremediavelmente morto; a própria sintaxe era um arcaísmo" (Idem, [s.d.], p. 3). Dirá ainda:

"Se isso [os sentimentos subjetivos] não importava para a poesia, eu simplesmente não estava interessado em poesia. (...) Ora, se essa era a poesia do momento, e a poesia do futuro, eu não tinha nenhum futuro como poeta. Esse impasse me levou a parar de escrever poesia por cinco ou seis anos." (Ibidem)

Somente quando entendeu que "o sujeito lírico é um construto, uma ficção elaborada pelo poeta não apenas para escrever poemas, mas para enfrentar certos problemas de sua vida" (Ibid, p. 6) e que "a voz lírica é claramente um aspecto vital da personalidade do autor, e não uma simples ficção autônoma desvinculadas das paixões e crenças do homem." (Ibid., 
p. 9), proposições que conferem humanidade ao sujeito lírico, Britto pode retomar a escrita da poesia, agora como um projeto existencial e estético, em que as memórias do lido e do vivido interagem na constituição de um "eu" lírico que ultrapassa a condição de mera instância discursiva e aflora como faceta de uma personalidade extraliterária.

Levantemos, então, uma hipótese: a "solução" poética encontrada por Britto seria índice de sua condição de poeta anacrônico e a manifestação da subjetividade, literária ou existencial, seria, de fato, marca do anacronismo. Generalizando, estaríamos impelidos a afirmar que a memória não exerce mais influência na produção poética atual?

Tomando a liberdade que um trabalho sobre o Tempo concede, subvertamos a ordem causal e, antes de discutirmos, no próximo tópico, a hipótese do anacronismo, diremos que o trabalho da memória não está ausente da poesia contemporânea, simplesmente por não acreditarmos ser possível um fazer poético que prescinda deste processo - quer queira, conscientemente, o poeta ou não.

No artigo "Traços de memória na poesia brasileira contemporânea", Celia Pedrosa discute o estatuto da memória em nossa atual produção poética. Aparentemente, essa poesia não reservaria espaço para a evocação do passado e a memória apenas apareceria como objeto de reflexão para ter seu valor questionado até a negação. Diante da efemeridade e da inapreensibilidade do tempo, e daquilo que nele se dissipa, a memória, como mecanismo de retenção, torna-se o ponto antitético e negativo do privilegiado fluir temporal.

O culto ao presente causa, entretanto, uma suspensão do fluxo temporal, entronizando "uma epifania do instante que reafirmaria a autonomia do olhar poético face às contingências da historicidade" (PEDROSA, 2000, p. 116). Ocorre, porém, que a força arrebatadora da memória impõe-se a este sujeito lírico incapaz "de organizar seus efeitos, impondo-lhes uma perspectiva, uma ordem, um sentido, uma direção" (Ibid., p. 119).

Obsediando, de modo espectral, a escritura e o sujeito lírico, o trabalho de uma memória involuntária "constitui seu sujeito como ser expectante, destituído de uma consciência prévia a partir da qual modelasse o tempo na direção de uma origem ou finalidade únicas" (Ibid., p. 120), expondo-o ao contínuo do porvir, da iminência do acontecimento, da vinda do seu próprio passado, dissociando o homem da consciência de seu passado. 
Pensando as observações de Célia Pedrosa por uma perspectiva benjaminiana, diríamos que a pressão exercida pela memória ressuscita o reprimido para a eternidade, para além da dicotomia lembrança / esquecimento. O passado, surgindo como uma injunção, obriga o poeta a lidar com ela, ainda que ele tente rejeitá-la, negá-la, denegá-la. Um passado selvagem que ameaça, com seus resíduos ainda não administrados pela História oficial ou pela racionalidade do sujeito, fazendo emergir conteúdos perturbadores a uma consciência que se deseja a-histórica.

Esta é propriamente a garantia de subsistência da poesia num mundo adverso. A resistência, se não constitui a essência ser da poesia, é o seu "modo historicamente possível de existir no interior do processo capitalista" (BOSI, op. cit., p. 143):

"Mesmo quando o poeta fala do seu tempo, da sua experiência de homem entre homens de hoje, ele o faz, quando poeta, de um modo que não é o do senso comum, fortemente ideologizado; mas de outro, que ficou na memória infinitamente rica da linguagem. (...) / Nessa perspectiva, a instância poética parece tirar do passado e da memória o direito à existência; não de um passado cronológico puro - o dos tempos já mortos -, mas de um passado presente cujas dimensões míticas se atualizam no modo de ser da infância e do inconsciente. A épica e a lírica são expressões de um tempo forte (social e individual) que já se adensou o bastante para ser reevocado pela memória da linguagem." (Ibid., p. 112)

O trabalho poético, como manifestação da memória, também encarna a tarefa de reinventar a herança humana. Utopia e nostalgia se confundem no presente da enunciação lírica, ainda que sob o signo do Anacronismo que, veremos, é menos que uma pecha, a égide do poético na contemporaneidade.

\section{II - A contemporaneidade da anacronia...}

O título deste tópico é, provocadoramente, um paradoxo, mas não um jogo de palavras vazio. Funciona como um alerta para a necessidade de se repensar os sentidos dos adjetivos contemporâneo e anacrônico, quando nos referimos à poesia, sob o risco de não conseguirmos ajuizar, de maneira crítica, o uso destes conceitos. 
Buscando-se o sentido vernacular das duas palavras, veremos que o substantivo anacronismo significa o ato de pôr algo fora do seu tempo correspondente, e a confusão de data quanto a acontecimentos ou pessoas. Já anacrônico, além de ser o que contém ou encerra anacronismo, é aquilo que está em desacordo e atraso com a moda e o uso; o que é avesso aos costumes hodiernos; e o que é retrógrado.

Tomando-se os dois sentidos mais abrangentes do termo, estaremos inclinados a concordar que estar fora do tempo hodierno não é, certamente, o mesmo que estar em atraso com a moda, ou que ser retrógrado. Anacrônico, pela primeira acepção, pode ser aquilo que está, numa suposta sucessão temporal, avançado em relação ao agora, podendo assumir um valor eufórico para quem o enuncia. Pela segunda definição, entretanto, o anacronismo possui valor disfórico, marcando a defasagem cronológica de algo que, aferrado ao passado, é contrário ao progresso entendido como um "bem".

Quando nos referimos ao anacronismo da produção poética, dizemos que a poesia está à frente de nosso tempo ou, ao contrário, é um gênero discursivo decrépito? O problema, podemos garantir, não é de hoje, nem se restringe ao contexto brasileiro. Na epígrafe deste artigo, transcrevemos um desabafo de Giacomo Leopardi que, no início do século XIX na Itália, questionava se a arte poética não estaria se tornando anacrônica, por ser regida por ideais incompatíveis com o degenerado mundo moderno. Para o poeta italiano, o anacronismo do poético era, em última análise, um fato positivo, pois indicava que a poesia não se coadunava com um momento histórico de degradação moral e espiritual.

O poeta e ensaísta alemão Hans Magnus Enzensberger, quase cento e cinqüenta anos mais tarde, irá considerar o hábito de se ler e escrever poemas o maior de todos os anacronismos de nossa época, chamando atenção para a inofensividade da prática poética nas sociedades midiáticas, tendo em vista o mínimo número de leitores que ela possui. Nesse caso, a anacronia da poesia tem um significado negativo, assinalando, ao menos em termos quantitativos, uma decadência na recepção da poesia.

Gostaríamos de acrescentar ainda uma dúvida crítica à coexistência dos sentidos latos da palavra anacrônico: escrever poesia hoje é, inevitavelmente, um anacronismo ou apenas alguns poetas e poesias são anacrônicos? Com esta questão, estamos em condições de formular quatro possibilidades de emprego do conceito: i) a poesia é uma arte "fora do tempo"; ii) alguns poetas são "fora do tempo"; iii) a poesia é uma arte "retrógrada"; e iv) alguns poetas são "retrógrados". 
Acreditando que as assertivas (i) e (iii) apresentam uma exigência de universalização que excede nossa força analítica, centraremos nossa discussão nas hipóteses (ii) e (iv), sem descartar o alcance mais geral que nossas observações, embora restritas a obra de Paulo Henriques Britto, possam assumir.

Como o anacronismo define-se em função de um eixo temporal, bastante instável, encarnado pelo presente, falta estabelecer uma definição de contemporaneidade. Antonio Cicero, em $\mathrm{O}$ mundo desde o fim, define "contemporâneo" como aquilo que é presentificável ou comparecível a mim - instância reconhecedora da contemporaneidade -, que estou empregando a palavra. Trata-se de uma relação comutativa: não se pode querer ser contemporâneo a coisas ou pessoas, já que elas só podem existir sendo minhas contemporâneas. Nos termos derridianos, diríamos que a contemporaneidade é uma injunção.

Falar em contemporâneo de maneira não relativa, absoluta, é não estar dizendo coisa alguma. Desejar o contemporâneo, portanto, nada mais é do que uma declaração sintomática: podemos pressupor que aquele quem fala acredita não estar no centro, mas na periferia do mundo. Pretender captar o novo é se condenar "à posição do não-moderno ${ }^{1}$ e provinciano em relação ao que considera como os centros produtores do novo" (CICERO, 1995, p. 173).

Paula Glenadel (2000) identifica o "contemporâneo" como uma categoria problemática. Possuindo a força de um imperativo, ele não se constitui exatamente como uma modalidade do presente. Citando o já referido trabalho de Jacques Derrida, a autora lembra da semelhança entre as tarefas do herdeiro e a do homem contemporâneo: o herdeiro, antes de herdar o "herdado", herda a injunção da herança; o contemporâneo herda a injunção do "agora", instância privilegiada da transformação e do devir.

\footnotetext{
${ }^{1}$ Cicero traça uma pontual distinção entre modernidade e contemporaneidade. "Moderno", adjetivo oriundo do advérbio latino modo "agora mesmo", é "o que toma por referência o agora; trata-se, em suma, do que podemos chamar de agoral' (CICERO, op. cit., p. 173). Agora pode ser tanto o contemporâneo ou presente quanto a sua negação. O agora traz consigo a potência (necessária, essencial, absoluta) do possível, da mudança e da indeterminação, realidade diferentes do que me é contemporâneo. "Agora poderia não ser isto ou aquilo mas, em hipótese alguma, agora deixaria de ser a possibilidade dessas ou de outras coisas" (Ibid.).
} 
Quando alguém declara, como em nossa hipótese (iv), que determinado poeta é anacrônico, porque retrógrado e portanto nãocontemporâneo, está dizendo muito pouco do autor em questão, mas traindo sua própria posição insustentável de avalista do "moderno", pois, ao afirmar que determinados fazeres poéticos são mais seus coetâneos do que outros, está negando o caráter impositivo da contemporaneidade.

Resta-nos, como única opção, a (ii): alguns poetas são anacrônicos pois estão "fora do tempo". Tal compreensão reconhece na anacronia a possibilidade de se lidar com a realidade "out of joint" ${ }^{2}$, na sugestão de Paula Glenadel (op. cit.). Se o mundo está fora dos eixos, o poeta habitaria um espaço de resistência onde sua fala está, por um átimo, livre das pressões dos eventos contingentes. No âmago desta questão, reside a convicção na aptidão do poeta de se colocar do lado de fora da linguagem. Jean-Paul Sartre acreditava que o poeta recusa-se a utilizar a linguagem e age por fora da convenção da língua. "O poeta está fora da linguagem, vê as palavras do avesso, como se não pertencesse à condição humana" (SARTRE, 1989, p. 14).

Viver fora do Tempo e da Linguagem é, provavelmente, uma impossibilidade. Mas compreender a temporalidade imanente da linguagem pode ser o motor de uma potente reflexão que libertará a memória inscrita no próprio material de trabalho do poeta - a língua, cuja própria estrutura, simultaneamente sincrônica e diacrônica, é pura manifestação da anacronia.

Ao evocar sentidos, sintaxes e sons latentes da língua, o poeta funda uma sincronia outra, virtual, acrônica, que se desfaz à primeira tentativa de categorização. A metapoesia recorrente, na obra de Paulo Henriques Britto e de outros poetas "anacrônicos", é um ponto de apoio para uma reflexão sobre o fazer poético e sobre a linguagem como instância liberadora da memória. Os fragmentos e resíduos de memória insurrecta, obsediando o sujeito lírico, respondem ao presente adverso, ao sentimento de "desencantamento do mundo", não apenas como uma reserva nostálgica de um passado sacralizado ou como combustível de imagens idealizadas para projetos utópicos, mas urgindo uma escrita poética

${ }^{2}$ Jacques Derrida refere-se a uma fala de Hamlet em que o herói trágico de Shakespeare amaldiçoa o destino que lhe fez nascer com a tarefa de consertar um mundo "out of joint", "fora dos eixos". 
empenhada no aproveitamento do "agora" como o momento único de reinvenção da herança, tarefa a que o poeta, cônscio de sua privilegiada sobrevivência anacrônica, não pode preterir.

\section{III - Poeta, pois anacrônico}

Não acredite nas palavras, / nem mesmo nestas, / principalmente nestas.

Paulo Henriques Britto, "Para não ser lido"

Paulo Henriques Britto publicou pela primeira vez no início dos anos oitenta, quando o cenário da produção poética apresentava um explícito embate estético entre os seguidores do experimentalismo concretista e os chamados "poetas marginais". A lírica introspectiva de Britto, repleta de formas, ritmos e métricas tradicionais, não podia ser facilmente alinhada a nenhum dos vetores poéticos dominantes dissonando, especialmente, da poesia de inspiração anti-literária que dominava o Rio de Janeiro na década de 70.

Esclareçamos, entretanto, que os decassílabos e os sonetos, ou "sonetóides" na definição do próprio poeta ${ }^{3}$, apresentavam acentos raros e hemistíquios inusitados, num expediente que vai ter como corolário o ciclo "Até segunda ordem" (BRITTO, 1997, p. 43), em que a forma soneto é dissociada dos valores de poesia "elevada e séria", transformando-se em mero recipiente para algo tão ordinário quanto um bilhete de integrantes do crime organizado. Antonio Cicero atenta para a necessária distinção entre a poesia e as formas que esta assume historicamente. A insubordinação dos poetas vanguardistas, por exemplo, não é contra a poesiaem-si, mas ao convencionalismo que aprisiona o fazer e normatiza o gosto poético. As estéticas de vanguarda, ao radicalizar essa tendência, apresentaram possibilidades inusitadas, ampliando o conceito do poético através de um conhecimento negativo nascido do despojamento de tudo o que há de contingente no poema, ensinando-nos assim que "a poesia não tem essência: a poesia é toda acidência”. (CICERO, op. cit., p. 23)

${ }^{3}$ Em entrevista a Rodrigo de Sousa Leão, conforme bibliografia. 
Sob essa perspectiva, poderemos situar Paulo Henriques Britto no contexto de coexistência "amena" de estilos, dicções e recursos poéticos característico da poesia contemporânea brasileira, ao mesmo tempo que dissociaremos da noção de anacronismo o fato de que ele emprega formas poéticas tradicionais. Como propomos anteriormente, a anacronia do poeta é uma ação de resistência, mobilizada pela memória, e concretizada numa escritura impregnada de metalinguagem ${ }^{4}$. A leitura que vamos propor aqui tomará esta vocação metalingüística como sendo uma estratégia que permite ao poeta lidar com as essenciais questões de memória e de linguagem.

No início deste trabalho, vimos que Britto resistiu à tendência do pensamento hegemônico contemporâneo, ao fabricar para si um "eu" num momento histórico em que o conceito de sujeito individual era, ou ainda é, apontado como um anacronismo. Cabe-nos averiguar a consistência deste "sujeito" que se estabelece no poema, e como ele é subordinado à ação de diversos tipos de memória. Comecemos pelo terceiro poema do ciclo "Sete estudos para a mão esquerda":

Sou uma história, a voz que a conta, e o imenso / desejo de contar outra diversa, / que porém não deixasse de ser essa. /(...) / (mas não era isso o que eu ia dizer, / e sim uma outra coisa, obscura e bela, / que sei, com uma certeza visceral, / ser a verdade última e total - / e só por isso já não creio nela, // pois a certeza, tal como a memória, / é por si só demonstração sobeja / da falsidade do que quer que seja) /(...). (BRITTO, 1997, p. 15)

A proposição existencialista do poema - sou a história e quem a conta - afirma que se é o que se faz de si, mas vem acompanhada de uma certeza, ou melhor, de uma certeza na ausência de certezas, que esboroa a idéia de um sujeito construído de modo pleno e absoluto no discurso poético. Embora cristalizado em formas perfeitas, por sobre as fissuras e incoerências do homem-poeta, o eu-lírico produzido é instável, pois configurado na e pela memória. Deste modo, o eu que se afirma é apenas "a intenção de ser alguém ou algo / que não se pode ser, mas só ter sido" (BRITTO, 1989, p.19), descrito em um dos "Dez sonetos sentimentais".

\footnotetext{
${ }^{4}$ Assim entendemos porque Britto afirma-se, na já citada entrevista a Rodrigo Leão, como um poeta típico de sua geração, em sua tendência à reflexão metalingüística, desenvolvida sob os auspícios de João Cabral de Mello Neto.
} 
Motriz da construção deste frágil sujeito, a memória, "demonstração sobeja da falsidade do que quer que seja”, assume variadas facetas na poesia de Britto. Num primeiro momento, ela é a apaziguadora possibilidade de trazer do passado a vontade e o desejo vivificantes, constantemente ameaçados de deperecimento pelo inexorável escoar do tempo, como em "Geração Paissandu", do ciclo "Álbum":

Vim, como todo mundo,/ do quarto escuro da infância,/ mundo de coisas e ânsias indecifráveis,/ de só desejo e repulsa./ Cresci com a pressa de sempre./(...) Agora a minha boca/ não arde tanto de sede./ As minhas mãos é que coçam -/ vontade de destilar/ depressa, antes que esfrie,/ esse caldo morno de vida." (Ibid., p. 71)

A necessidade de escrever antes que o tempo consuma "o caldo morno da vida" justifica-se pela concepção que o poeta tem da temporalidade. No poema "Materiais", ele não duvida de que a utilidade do tempo é o silêncio (Ibid., p. 54), convicção reiterada a si próprio no quarto poema da série "No alto":

Cuidado, poeta: o tempo engorda a alma./ Depois de um certo número de páginas/ anjos não pousam mais nas entrelinhas./ E até a lucidez, essa moderna,/ também se gasta, como qualquer moeda.// O ter o que dizer é jogo arriscado, /(..)/ O tempo é escasso. O dicionário é gordo./ Cuidado: todo silêncio é pouco. (Idem, 1997, p.121)

O tempo conduz ao silêncio ou ao risco de um uso de linguagem à margem da "lucidez, essa moderna", quando não mais somos conscientemente responsáveis pela usina de imagens da memória. A ameaça constante da ação do esquecimento fará o poeta se perguntar, no segundo poema da série "Bonbonnière", se "foi mentiroso o passado / ou a memória mentiria?" (Ibidem, p. 97). A dúvida inaugura a percepção da incompatibilidade perigosa entre uma memória que se esvanece e sua transubstanciação em palavras. É a segunda face da memória na poesia de Britto, quando ela aparece como incompletude, sob o signo do esmaecimento, como virá explícito nos versos seguintes, da mesma série:

Nada devolve o ato. A escrita engana,/ engole a frio e a seco o mau bocado/ e faz uma careta, consolada.//(...)/ nada revoga o fato. A escrita embroma// mas não abole o acaso consumado,/ não redesperta o desejo rendido/ nem morde tantas bocas mal beijadas/ e o momento ridículo persiste,/ engalanado, feito um monumento,/ imune ao tempo, ao vento, a todo verso (...) (Ibidem, p. 99) 
A escrita engana pois consegue, com sua potência lógico-discursiva, mascarar o insolúvel e estabilizar o que há de errante na memória que se desvanece. É a traição da língua que vemos em "Sonetilho de verão": "Traído pelas palavras. / O mundo não tem conserto. /(...)/ A idéia resiste ao verso, / o verso recusa a rima, / a rima afronta a razão / e a razão desatina. / Desejo manda lembranças. / (...) (Ibidem, p. 81). Entretanto, a memória feita palavra não é a reedição do Mesmo. Entre o ato apreendido, irrecuperável em sua plenitude, e sua evocação, escorre o tempo. Assombrada pela memória insurrecta, a língua, por si só, não nos livra do "desejo que manda lembranças". Assim, no último poema da série "Bonbonnière", o poeta lamenta: "Remorso manso, sem dentes, / do já vivido e apagado. /(...)/ A vida não quis esperar. // Memória, / mãe amorosa de todas as mortes." (Ibidem, p.103).

A melancolia de um passado irremediavelmente morto constitui a terceira face da memória, "mãe amorosa de todas as mortes". Para não sucumbir à prostração e à passividade de mero espectador do rito nostálgico da memória, o poeta precisa retomar as rédeas dos mecanismo da lembrança. No poema "Flyleaf":

"Not to remember's not the same/ as to forget:/forgetting is an act of will,/ not just a lack./ It takes just time/ not to remember any more./ Forgetting takes time and more:/ takes force, tact, a certain/ contempt for mere fact./(...)" (Idem, 1989, p. 73)

Ao discernir o não-lembrar do esquecer, uma outra distinção, análoga, insinua-se: entre a lembrança, como sendo uma ato da vontade, e a reminiscência, como efeito de uma memória involuntária. A tarefa do poeta, ser anacrônico, é resistir, tomando para si a extremada tarefa da lembrança (e como já dissemos com Derrida, tarefa da herança): escolher. No primeiro poema do ciclo "Bonbonnière":

A seletividade da memória - /(...)/ - falsa perfeição, mero artifício / do tempo, a desmaiar todos os tons / do que destoaria do desejo // como um menino a retirar sem pejo / da caixa que lhe deram os bombons / de que ele abre mão sem nenhum sacrifício. (Idem, 1997, p. 95)

$\mathrm{Na}$ fina percepção de Silviano Santiago, o passado, como lugar da reflexão, "não tem um valor em si que deve ser preservado a todo custo, mas pode e deve ter um valor que lhe é dado pelo horizonte de expectativas do presente" (SANTIAGO, 1981, p. 85). Britto compara a 
atividade do lembrar à tarefa de um numismata e a de um taxidermista de cadáveres, no terceiro poema do ciclo "Noites brancas":

Há algum tempo coleciono cadáveres./ Minhas gavetas não têm mais lugar. / Eu curto o prazer meio besta / dos numismatas e taxidermistas. / Meus mortos gozam a eternidade postiça / dos bálsamos e etiquetas. / / E assim convivemos todos / na mais perfeita urbanidade / (...) (Idem, 1989, p. 75-77)

Ordenando os vestígios do passado, o poeta-numismata-taxidermista enfrenta o Tempo, que prenuncia a dissipação da lembrança e o emergir furioso da reminiscência. Entramos no território da insônia, tema que obsidia Britto, por ser a alegoria do estado ideal para a assunção daquilo que é renegado, para o irrompimento dos resíduos do trabalho da lembrança:

Na solidão inconfessa do amor/ de vez em quando alguma coisa incômoda/ vem até a tona para respirar,/ e nos contempla, muda, encabulada,/ com a língua imunda de fora, a arfar./ Não que não soubéssemos que no fundo/ da doce felicidade possível/ sobrevivia alguma criatura/ fria e estúpida como essa, esperando/ sem pressa um momento insatisfeito/ de insônia para nos atacar (...). (Ibid., p.25)

A consciência insone é o campo adequado para se lançar a "semente de coisas adormecidas":

Na noite imperturbável,/ infinitamente leve/ a consciência se esbate,/ espécie de semente/ sobre um campo de neve// neve macia e negra/ intensamente morna/ onde o tempo se esquece/ na inércia indiferente/ das coisas que só dormem // onde, alheia ao mistério/ de tudo ser evidente,/ inteiramente encerrada/ dentro do espaço exíguo/ que é dado a uma semente// inútil como fruta/ que não foi descascada/ e apodreceu no pé,/ jaz a semente aguda/ profundamente acordada (Idem, 1989, p.55).

No primeiro poema da série "Três lamentos", Britto enumera, entre os "trastes do ofício", a insônia: "Inevitável a lembrança/ que a noite arrasta consigo/ no mesmo saco que o escuro,/ a insônia, o tédio, as estrelas/ e os outros trastes do ofício" (Ibidem, p.29). Momento privilegiado do labor poético, a "hora má" da insonolência é o grau máximo da anacronia, quando tudo parece parar, menos o poeta: 
entre as exumações da insônia/ e os sóbrios sortilégios da sintaxe/ enquanto o mundo inteiro dorme/ (...)/ menos a mão enorme// a qual insiste no ritmo aflito/ de quem procura mas não vê saída/ do labirinto desta hora/ má, de espelhos amordaçados/ e maçanetas mortas. (Idem, 1997, "Aranha", p. 69)

O poema, frágil produto do estado de insônia, não tem como reter a torrente de imagens da reminiscência: "Inevitável esse espaço/ que já não guarda mais nada/ do que a memória gravou/ com marca de ferro em brasa,/ do que cravou na memória/ como só um corpo se crava." (Id., 1989, p. 29) Mas, o poeta, o anacrônico, não se rende. Há algo que pode irromper do transe da insônia, e que lhe interessa. Talvez haja, em algum lugar do passado, um momento em que as imagens, as coisas e os nomes eram uma única entidade: "Tudo era muito grande e longe./ O tempo era uma lagarta enorme/ sem patas. Era sempre agora.// Cada coisa tinha um nome./ O nome explicava tudo./ Ter nome era o mundo. (Ibid., "Mantra", ciclo "Álbum", p. 70). Seria possível, pelo trabalho poético, reatualizar este instante pré-categorial, hora exata em que o mundo se encharca de palavras? Há uma sugestão, no poema "Dos nomes":

Se tudo que se pode revestir/ da couraça inconsútil da palavra/ fosse algo mais que um vácuo protegido - / se atrás de todo nome houvesse sempre/ alguma coisa concreta, capaz/ de se deixar quebrar - se todo nome/ fosse máscara e não rosto, e a coisa/ fosse o fogo que há sempre onde há fumaça -/ falar seria então sempre dizer,/ dar nome à coisa não seria mais/ que ver na superfície da semente/ a planta por nascer; e a sensação/ incômoda de estar a todo instante/ em algum lugar - isso seria ser. (Ibid., p. 41)

Existir fora da linguagem, já dissemos, é um trabalho além das forças do poeta. Mas ele não se entregará, sem esmiuçar o perverso mecanismo lógico instaurado pela linguagem, que é capaz de harmonizar sintaticamente o caos da sensibilidade humana:

A coisa parece fácil:/ o fora em torno do dentro,/ o alto em cima do baixo.// Mas essa ordem serena/ é coisa dura e avessa,/ uma máquina perversa.// Para instaurar esse mundo/ precisa a vontade mais crassa,/ a desfaçatez de quem sempre/ procura aquilo que acha./(...) (BRITTO, 1997, "Sete estudos para a mão esquerda (IV)", p. 25)

Na cínica ordem conciliadora da língua, o mundo seguirá "opaco" como uma paisagem clichê, incapaz de oferecer alguma informação nova: 
Nenhuma lição nesta paisagem/ que não o fartamente conhecido:/ as coisas nos lugares, engrenagens// do estar-em-si, do tudo-é-relativo,/ (...) - O mundo segue opaco,/ imune à consciência e seus lampejos/ de lógica, sua falta de tato,/ sua avidez, seus deuses e desejos.// (Aqui termina o sonho. Fim das névoas,/ caramelos e almofadas formidáveis./ Daqui pra frente, as portas sem remédio/ $\mathrm{E}$ todas as maçãs assassinadas.)" (Ibid., "Sete estudos para a mão esquerda (VI)", p. 29)

O poeta entrevê o mal e, se não conhece a cura, trabalha com um lenitivo: a radicalização da escrita, sem o qual se torna mais usado do que usuário da linguagem. Em "Piada de Câmara":

"A invenção da palavra/ desinventa o real/ e põe no lugar da coisa/ um enfezado matagal -/ mistura de a coisa haver/ com não haver coisa tal./ E quem ao pé desse mato/ tocaia algum animal/ que tenha pé e cabeça/ pele escama pêlo ou pena/ encontra mesmo é um poema/ afinal. (Id., 1989, p. 38)

A "invenção" da linguagem é tão maravilhosa e esfuziante que o mundo começa a parecer não existir. Por isso o poeta vai viver a linguagem, revitalizando uma metáfora antiga, como uma porta, entre dois mundos que mantêm uma relação de mútua exclusão. Diante dela, dois procedimentos são possíveis:

"Noites brancas" fala da atitude conformada diante da linguagem: "Subir a escada, abrir a porta/ sem expectativa de encontrar/ coisa nenhuma que não esteja/ em seu exato lugar." (Ibid., p. 75). No ciclo "Dez exercícios para os cinco dedos", outros indícios de passividade:

I - Precisamente ali/ no intervalo entre a vontade e o desejo/ ali na parede, o interruptor/ da lâmpada que lança sobre tudo/ a cal abrupta da realidade,// capaz de avassalar a escuridão/ arredondando os ângulos agudos/ como uma chave líquida que abrisse/ todas as portas. Porém você/ não precisa de portas. (Id., 1997, p. 47)

V - Alguém reclama: A porta está fechada./ E não é que está mesmo? Antes assim./ Podia ser pior. (...) (Ibid., p. 55)

A outra atitude, poética, seria buscar a maçaneta franqueadora da porta da linguagem, como no primeiro poema de "Duas fábulas sem moral":

A door opens into the unkown,/ you walk right in, you make yourself at home./(...)/ Behind the sofa is a dark corner, which you look into/ 
just in time to catch one flashing glimpse/ of the gleaming white teeth Unknown,/ who grins at you, and with a click is gone forever (Id., 1989, p. 59).

No átimo do entreabrir da porta, instante da anacronia proporcionado pela visada poética, revela-se a missão do poeta, não mais o numismata-taxidermista, mas agora o "funâmbulo" do poema homônimo: "Entre a palavra e a coisa/ o salto sobre o nada." (Id., 1997, p. 15). Sobre o abismo entre a linguagem e o mundo, o poeta-funâmbulo equilibra-se, desconfiando da linguagem, amaldiçoando-a, por se prestar a quaisquer usos. Decide salvá-la, pois sabe que sua própria salvação depende desse sucesso.

A solução difícil. As adversárias./ Escrever a contrapelo do papel./ E aquela que acabou sendo riscada -/ Calou-se, escapuliu, não se rendeu -/ era precisamente a procurada./ Sobrou só isso que, leitor, é teu./ Só isso, sim. Que ao mesmo tempo é tudo./ Um suscitar de sílabas - não mais/ a deusa atarantada a nos soprar/ um vento em nosso ouvido (aliás surdo)-// e no entanto cabe dentro um mundo,/ um universo, um homem a espernear./ Um que afinal domou as adversárias,/ essas palavras que me deixam mudo. (Ibid., p. 31)

Escrever torna-se uma luta pela, contra e na linguagem. Entre o escolhido e o excluído, entre o suscitar de sílabas e o vento soprado pela deusa atarantada, a vitória do poeta é superar a mudez e a errância que nos são impingidas pela ação profunda do tempo sobre a linguagem. Vaticina Paulo Henriques em "Para não ser lido": "Não há fala/ que negue/ o que cala" (Idem, 1989, p. 69).

Instância tanto de salvação quanto de perdição da condição humana, a linguagem não é o mundo, mas é só o que nos restará dele, caso negligenciemos nosso direito de livre passagem pela porta. A linguagem, como a lembrança, como a herança, é também uma tarefa do homem: "Existir é muito pouco.// Por isso, por isso os nomes,/ os nomes se engastam nas coisas/ e sugam o sangue de tudo $/(.$.$) / e roubam do$ mundo a paz /de não querer dizer nada. // 3. Bendita a boca,/ essa ferida funda e má." (Ibid., "Elogio do mal", p. 52-53) 


\section{Referências Bibliográficas}

AQUINO, Marcela Ferreira Medina de. Ave, palavra: a inauguração do mundo no romantismo alemão. Monografia apresentada ao curso "Poesia e contemporaneidade", Pós-graduação em Letras, UFF, 2000. (mimeo.)

BARTHES, Roland. Aula. São Paulo: Cultrix, 1997.

BENJAMIN, Walter. "Sobre o conceito da história". Magia e técnica, arte e politica. Trad. Sérgio Paulo Rouanet; Pref. Jeanne Marie Gagnebin. 7. ed. São Paulo: Brasiliense, 1994. p. 222-232.

BENVENISTE, Emile. Problemas de lingüistica geral. Vol. 2. Campinas: Pontes, 1994.

BERGSON, Henri. Matéria e memória. São Paulo: Martins Fontes, 1990.

BOSI, Alfredo. Dialética da colonização. 3. edição. São Paulo: Companhia das Letras, 1996.

. O ser e o tempo da poesia. São Paulo: Cultrix, Ed. da Universidade de São Paulo, 1977.

BRITTO, Paulo Henriques. Algumas reflexões sobre tradução e criação poética. Mimeo., [s.d.], p. 1-7.

Minima lírica / Liturgia da Matéria (1982-1989). São Paulo: Duas Cidades, 1989.

. "Poesia e Memória" in PEDROSA, Celia (Org.). Mais poesia hoje. Rio de Janeiro: 7Letras, 2000. p. 124-131.

. Trovar claro. São Paulo: Companhia das Letras, 1997.

CAMPOS, Jorge Lúcio. "Resenha de Trovar Claro, de Paulo Henriques Britto". Jornal de Poesia. www.secrel.com.br/jpoesia/jlucio13.html.

CICERO, Antonio. O mundo desde o fim. Rio de Janeiro: Francisco Alves, 1995. . Poesia e paisagens urbanas. In: PEDROSA, Celia (Org.). Mais poesia hoje. Rio de Janeiro: 7Letras, 2000. p. 16-124.

DERRIDA, Jacques. Espectros de Marx: o Estado da dívida, o trabalho do luto e a nova internacional. Trad. Anamaria Skinner. Rio de Janeiro: Relume Dumará, 1994.

DICIONÁRIO AURÉLIO ELETRÔNICO - SÉCULO XXI. Versão 3.0. Lexicon Informática, 1999. 
ENZENSBERGER, Hans Magnus. Mediocridade e loucura e outros ensaios. São Paulo: Ática, 1995.

FOUCAULT, Michel. Linguagem e Literatura. In: MACHADO, Roberto. Foucault, a filosofia e a literatura. Rio de Janeiro: Jorge Zahar, 2000.

. O que é um autor? Trad. de António F. Cascais e Edmundo Cordeiro. Lisboa: Vega, 1992.

GAGNEBIN, Jeanne Marie. História e narração em Walter Benjamin. São Paulo: Perspectiva, 1997.

GLENADEL, Paula. Contemporaneidade e aporia na poesia de Alexei Bueno: Ser e não-ser. Trabalho apresentado no XV Encontro da ANPOLL, GT: Teoria do Texto Poético. Mimeo., 2000.

HOLlANDA, Heloísa Buarque de (Org.). 26 poetas hoje. 2. ed. Rio de Janeiro: Aeroplano Editora, 1998.

. Esses poetas: uma antologia dos anos 90. Rio de Janeiro: Aeroplano Editora, 1998.

LEÃO, Rodrigo de Souza. Entrevista com Paulo Henriques Britto. Jornal de Poesia. www.secrel.com.br/jpoesia/r2souza06c.html

LEITE, Cláudia Valéria. Palavras adversárias, poeta impostor? Monografia apresentada ao curso Poesia e contemporaneidade, Pós-graduação em Letras, UFF, 2000. (mimeo.)

NUNES, Benedito. O tempo na narrativa. São Paulo: Ática, 1988.

PEDROSA, Celia (Org.). Mais poesia hoje. Rio de Janeiro: 7Letras, 2000. Traços de memória na poesia brasileira contemporânea. (p. 113-121).

RANCIÈRE, Jacques. Políticas da escrita. Trad. e Raquel Ramalhete et al. Rio de Janeiro: Editora 34, 1995.

RORTY, Richard. Pragmatismo: a filosofia da criação e da mudança. Cristina Magro e Antonio Marcos Pereira (Org.). Belo Horizonte: Ed. UFMG, 2000.

SALLES, Écio de. O que quer o que pode essa lingua? Cine-olho: questões de identidade na poesia de Ricardo Aleixo. Monografia apresentada ao curso "Poesia e contemporaneidade", Pós-graduação em Letras, UFF, 2000. (mimeo.)

SANTIAGO, Silviano. Em liberdade. Rio de Janeiro: Paz e Terra, 1981.

SARTRE, Jean-Paul. Que é a literatura? São Paulo: Ática, 1989. 
STEVENS, Wallace. Poemas. Sel., trad. e intr. de Paulo Henriques Britto. São Paulo: Companhia das Letras, 1987.

WITTGENSTEIN, Ludwig. Os pensadores. São Paulo: Nova Cultural, 1991.

\section{Resumo}

Estudo crítico da poesia de Paulo Henriques Brito, a partir da problematização do conceito de contemporâneo e anacrônico.

\section{Résumé}

Etude critique de la poésie de Paulo Henriques Brito, à partir, surtout, de la problematization des concepts tels que "contemporain" e "anacronique". 